\title{
Cooperative Learning in English Writing Teaching
}

\author{
Hui Guo \\ College of foreign languages, Bohai University, Jinzhou, 121013, China \\ 953793256@qq.com
}

\section{Keywords: cooperative learning; English writing; college English teaching}

\begin{abstract}
Cooperative leaning stresses the learner-centered class, in which the teacher plays the role of director, supervisor and helper and students help each other to study some materials and can be rewarded for the achievements or performances of the entire group. This research aims to explore the effects of the application of cooperative learning on students' writing abilities and attitude in English writing. The author chooses two classes with 102 students as the participants from a university in the northeast of China. One class is randomly selected as the control class, while the other is chosen as the experimental class. The control class is adapted with traditional approach. Cooperative writing approach is applied in experimental class. The research attempts to find out cooperative learning can help students arouse their interest towards writing and it can help improve students' writing competence.
\end{abstract}

\section{Introduction}

Writing is one of the four basic skills a university student has to learn in the course of learning English. With the rapid development of economic globalization, English, the most widely used international working language, is a bridge for people to understand each other. Furthermore, English writing has been one of the most important communicative ways in which people express and exchange their ideas. Trends in the teaching of writing in ESL and other foreign languages have, not surprisingly, coincided with those of teaching of other skills, especially listing and speaking. [1] What's more, the points of English writing have recently increased in different national English tests. It is obvious that the demands on the writing competence are much higher for university students nowadays. However, there are still many problems of teaching and learning English writing existing in universities and colleges. On the one hand, the teachers do not pay enough attention to teaching English writing. They usually devote much time to grammar, vocabulary, and reading comprehension. Often in writing class, the teacher assigns a writing topic and students finish it within a given time and hand in their final compositions, finally the teacher corrects and grades students' compositions. Gradually, students always practice writing in this dull way, thus the students may lose motivation and interest in English writing and their ability of writing can not be obviously improved. On the other hand, English writing is a headache thing for the students. Students have low motivation and negative attitudes towards writing, they feel it difficult and boring to write something. [2] They have nothing in mind or they do not know how to express what they want to say. So it is necessary to make a further study on the teaching approach of English writing in universities. The author is curious about the prospect of using cooperative learning in students' writing. This study aims to prove whether cooperative learning is effective, feasible, writing teaching for university students.

\section{Cooperative Learning}

Cooperative learning has been defined in different ways and implies a number of related methods of organizing classroom activities. Nemours experts have their own definitions to definite cooperative learning.

Slavin describes that cooperative learning is a teaching approach, which students work in small groups to learn together. In cooperative classroom, students are supposed to help each other, to discuss and exchange ideas, to evaluate each other's knowledge. In other words, students working in 
groups in which they not only have the responsibility for their learning, but also for their group members.[3]

Johnson and Johnson define cooperative learning in this way: cooperative learning is the joint efforts of small group to maximize their own structure and each other's learning. From this point of view, cooperative learning is working together to accomplish a common goal. It is a teaching strategy that organizes classroom activity by arranging students in small groups so that they can support each other's learning. It is also a teaching approach that develops academic skills and social skills.[4]

Cooperative learning is also defined by other experts to be cooperative activities organized so that learning is dependent on the social structure, which each learner has to be responsible for his or her own learning. Learners exchange information to improve others' learning. To put it more concretely, cooperative learning provides an equal opportunity for every student to participate in the activities and encourage each student to make joint efforts and contribute to the group.

Chinese scholar, Wang Tan defines cooperative learning as "a kind of activity guided by aim." He points out that cooperative learning is a very effective teaching theory and strategic system. Students of different performance form pairs or small groups to work together in order to benefit from sharing ideas and achieve common goals. It aims at promoting the cooperative ability of students in a heterogeneous group.

In cooperative class students participate in class activities. Their writing will be read by other group members whose ability is similar to theirs. This is an effective way for students to learn from each other. In this process of reading, students can find their own mistakes. Many studies have showed the efficiency of peer assessment in improving English writing ability. And the teacher chooses some good compositions as good samples for other students to learn to read. This method can enhance the students' motivation and interests of writing and it can produce a comfortable and enjoyable learning environment and reduce conflict and anxiety.

Cooperative learning encourages students to work together and promotes an equal opportunity for every student to participate in the activity. Students' thoughts can be inspired by working together. When students finish writing, peer editing also provides a good opportunity for students to learn from each other. What's more, cooperative learning creates a positive atmosphere in the classroom. It enhances students' self-confidence, promote students' self-esteem, arouse greatly their learning interest, and improve their cooperative abilities [6].

To sum up, cooperative learning is an effective teaching approach in which students work in groups in order to accomplish the common goals. Each member of a group is responsible not only for learning what has learnt but also for helping group members to get cooperative achievement.

Learners can benefit a lot from cooperative learning. First, it can help students construct their own knowledge, absorb their knowledge, and have more interaction and communication opportunities. Second, positive interdependence among group members plays an important role in interpersonal interaction and social activities and thus leads group members to high emotional involvement thus improves their achievement in learning. Third, in cooperative learning activities, the students help each other what they know by explaining to other group members, which is not only beneficial to the giver but also to the receivers for maintaining information in memory. Fourth, social activities and interaction play a crucial role in cooperative learning. Students can develop their abilities of communication and interaction through the cooperative learning.

\section{Research Methodology}

This paper mainly discusses the application of cooperative learning to English writing teaching in universities. The purpose of the study is to see whether the method is more effective than the traditional one.

The participants in this research were 102 students in a northeast university in China. Class One with 50 students was selected as the experimental class and Class Two with 52 students was selected as the control class. In the experimental class, cooperative learning approach was 
conducted, while the traditional approach was applied in the control class. They were taught by the same teacher. The experiment lasted for one semester, from September 2014 to January 2015.

Test papers are used as a direct and effective tool to measure the students' English writing proficiency in the two classes and to testify teachers' teaching strategies. In order to guarantee the reliability and validity of the tests, the author adopted the writing part in CET-4 (College English Test Band 4 in China) as pre-test and post-test. The pre-test was administrated by both of the experimental class and the control class at the beginning of the semester in September, 2014, so as to test if they had the same level and ability of writing. The post-test was given at the end of semester in January 2015. The test was used to see whether cooperative learning was effective on students' English writing ability.

Two questionnaires were designed at the beginning and the end of the teaching research. The first questionnaire was conducted to see if there was much significant difference between the experimental class and the control class in writing attitudes and proficiency before the experiment. The aim is to get basic information about the students' previous learning background, learning habit, class performance and their attitude towards cooperative learning in English writing. The second questionnaire was used only for the experimental group at the end of the experiment. The aim of it is to get the information about the students' reaction to the method of cooperative learning in writing after a semester's study and get feedback on the effects of the cooperative learning in writing.

Teaching procedures in experimental class go like that: (1) students were divided into twelve groups with four or five students in each one. These students whose performance levels range from low to average to high and the average level of all the groups in the class is approximately equal. (2) The teacher gave some training to the students such as introducing some cooperative learning skills, explaining how to work together to accomplish the common goal. (3) After grouping and training, the teacher would carry out the writing task in writing class. A composition was assigned to each group according to what they had learned. (4) Students' activities in cooperative writing which consists of five steps. The first step is teacher's offering writing tasks (5 minutes).The second step is group discussion (5-10 minutes). Students were encouraged to discuss, work together, exchange views and share their ideas, work out the main content of the passage. The third step is cooperative writing which was the central step of the writing process. (15 minutes) Students carried out peer writing activities and individual writing. They were required to create a draft of their writing and note down what they were thinking based on the previous steps. At the same time, the teacher supervised the process of each group, offering help when necessary. The fourth step is peer revision and editing (15 minutes). The last step is the teacher's assessment which was necessary for students to point out both merits and demerits in the students' writing.

After the experiment, an interview was conducted on eight students from the experimental class. The aim of the interview was to get more information of students' opinions on the cooperative learning in English writing. They were asked some open questions to express their opinions about these cooperative writing activities so that the author could know the students' attitude toward cooperative learning in English writing and whether this kind of writing method can arouse their interest in English wring.

\section{Results and Discussion}

In order to know what had happened to the students' attitudes towards English writing and whether in some way students' writing competence had been improved. The author collected all the data from the questionnaires and writing tests. The pre-questionnaire and post-questionnaire were carried out both in experimental class and control class before the experiment and after the research in order to collect some learning background information and attitude towards English writing. The questionnaires consists of 11 questions, each of which was a statement about the students' confidence, attitudes and motivation about their English writing. Table 1. Indicates the statistics of the pre-questionnaire and the post questionnaire in the Experimental Class. 
Table 1. Statistics of pre-questionnaire and post-questionnaire in $\mathrm{EC}(\mathrm{n}=50)$

\begin{tabular}{|c|c|c|c|c|c|}
\hline Questions & $\begin{array}{l}\text { Question- } \\
\text { naires }\end{array}$ & $\begin{array}{l}\text { strongly } \\
\text { agree }\end{array}$ & agree & disagree & $\begin{array}{l}\text { strongly } \\
\text { disagree }\end{array}$ \\
\hline \multirow{2}{*}{ (1) I'm interested in English writing. } & Pre- & $18 \%$ & $28 \%$ & $39 \%$ & $15 \%$ \\
\hline & Post- & $22 \%$ & $35 \%$ & $31 \%$ & $11 \%$ \\
\hline \multirow{2}{*}{ (2) I find it difficult to write. } & Pre- & $66 \%$ & $20 \%$ & $14 \%$ & $10 \%$ \\
\hline & Post- & $40 \%$ & $16 \%$ & $26 \%$ & $18 \%$ \\
\hline \multirow{2}{*}{ (3) I have motivation in writing. } & Pre- & $26 \%$ & $26 \%$ & $36 \%$ & $12 \%$ \\
\hline & Post- & $36 \%$ & $36 \%$ & $20 \%$ & $8 \%$ \\
\hline \multirow{2}{*}{ (4) I often express my ideas in class. } & Pre- & $10 \%$ & $19 \%$ & $41 \%$ & $30 \%$ \\
\hline & Post- & $51 \%$ & $27 \%$ & $13 \%$ & $9 \%$ \\
\hline \multirow{2}{*}{$\begin{array}{l}\text { (5) I have confidence in my ability of } \\
\text { writing. }\end{array}$} & Pre- & $13 \%$ & $27 \%$ & $48 \%$ & $12 \%$ \\
\hline & Post- & $27 \%$ & $41 \%$ & $20 \%$ & $12 \%$ \\
\hline \multirow{2}{*}{ (6) I believe I can write well. } & Pre- & $14 \%$ & $36 \%$ & $35 \%$ & $15 \%$ \\
\hline & Post- & $25 \%$ & $46 \%$ & $19 \%$ & $10 \%$ \\
\hline \multirow{2}{*}{$\begin{array}{l}\text { (7) I practice writing because I like } \\
\text { English. }\end{array}$} & Pre- & $21 \%$ & $29 \%$ & $29 \%$ & $21 \%$ \\
\hline & Post- & $30 \%$ & $36 \%$ & $20 \%$ & $14 \%$ \\
\hline \multirow{2}{*}{$\begin{array}{l}\text { (8) I often discuss with my classmates } \\
\text { when I have problems. }\end{array}$} & Pre- & $2 \%$ & $11 \%$ & $66 \%$ & $21 \%$ \\
\hline & Post- & $57 \%$ & $21 \%$ & $13 \%$ & $9 \%$ \\
\hline \multirow{2}{*}{$\begin{array}{l}\text { (9) I will correct my composition after } \\
\text { finishing writing. }\end{array}$} & Pre- & $27 \%$ & $41 \%$ & $22 \%$ & $10 \%$ \\
\hline & Post- & $40 \%$ & $48 \%$ & $12 \%$ & $0 \%$ \\
\hline \multirow{2}{*}{$\begin{array}{l}\text { (10) I read my classmate's } \\
\text { composition. }\end{array}$} & Pre- & $4 \%$ & $22 \%$ & $50 \%$ & $24 \%$ \\
\hline & Post- & $31 \%$ & $44 \%$ & $17 \%$ & $8 \%$ \\
\hline \multirow{2}{*}{ (11) I make an outline before writing. } & Pre- & $21 \%$ & $47 \%$ & $19 \%$ & $13 \%$ \\
\hline & Post- & $33 \%$ & $52 \%$ & $10 \%$ & $5 \%$ \\
\hline
\end{tabular}

Note: (1). ( $\mathrm{n}=50)$ means that 50 students answered the questionnaires, and their answers are summarized here. (2). $\mathrm{EC}=$ Experimental Class.

Based on the analysis in the table above, the students' attitude towards English writing in EC undergo an obvious change after the experiment. Based on the comparison between the pre-questionnaire and post- questionnaire, it can be noticed that the students' in the experiment class have more confidence and motivation in English writing. The students are more eager to participate in the process of writing actively. More students developed good habit of writing, such as making an outline before writing, correcting after writing and would like to learn from each other among the students. They show much interest in English writing. Many students are willing to study English writing by themselves and in addition more students are willing to study English.

The pre-test was conducted to find whether the two classes were equivalent in their English writing competence. The result showed there were no obvious distinctions between the experimental class and control class before the experiment. Table 2 shows that there is obvious difference between the scores of the two classes after the experiment.

Table 2. Statistics of pre-test and post-test in CC and EC

\begin{tabular}{c|c|c|c|c|c|c|c|c}
\hline & Class & $\mathrm{N}$ & Mean & & Clas & $\mathrm{N}$ & Mean & $\begin{array}{c}\text { Increased by (\%), in } \\
\text { comparison with pre-test }\end{array}$ \\
\hline \multirow{2}{*}{ Pre-test } & CC & 52 & 14.8 & \multirow{2}{*}{ Post-test } & CC & 52 & 15.0 & 0.2 \\
\cline { 2 - 9 } & EC & 50 & 14.4 & & EC & 50 & 17.6 & 3.2 \\
\hline
\end{tabular}


It can be seen clearly in Table 2 that the mean of control class in pre-test is 14.8296, and in the post-test is 14.9808. The score of post-test is a little higher than that of pre-test. The mean of experimental class in pre-test is 14.3600 , in post-test is 17.5800 . The score of post-test is much higher than that of pre-test. Apparently, the progress of the experimental class is significant, while in control class no rapid progress has been made. So the students in the experimental class have made a significant progress in writing competence.

Interview is another effective research method of communication between the English teacher and the students in terms of cooperative learning. The purpose of the post-interview was to find the students' perception of the experience of this cooperative writing experience. After sixteen-week cooperative writing training, the interview was conducted in the experimental class. Eight students were selected to talk to the teacher about their ideas. Three students belong to high-mark group, three students come from middle writing level and the other two are low-mark group judging from the post-test. Through the interview, the researcher found though negative comments exited most of the students made positive comments on the approach. Most students are in favor of cooperative learning in English writing class and they enjoyed the atmosphere of such kind of English writing. Cooperative learning helps students to improve their English writing interest and their English proficiency.

\section{Conclusion}

This paper demonstrates that cooperative learning method has a positive and efficient influence on English writing teaching. According to the analysis of the data from the two tests, two questionnaires and the interview, some major findings can be drawn from the study. First, the cooperative approach to teaching writing stimulates students' interest and arouses their enthusiasm in writing. The students' motivation, and self-esteem are enhanced as well. This kind of teaching approach reduces the students' anxiety in English writing. Second, the learning atmosphere in class is relaxing. Students are eager to take part in the class activities. Third, students' English writing scores have been improved with implementation of cooperative learning in English writing class.

According to the research, implications can be drawn as the following. First, teachers should pay more attention to their students' learning rather than focus on their own teaching. Second, teachers should encourage students to participate in the activities bravely and actively, and encourage students to come up with ideas and opinions as much as possible. Third, the mistakes or errors in students' writings needn't to be corrected all by the teachers. They should be encouraged to correct by their peers. However, cooperative writing is more challenging for teachers, because teachers have to not only deal with the products of writing, but also the process of writing.

\section{References}

[1] Brown, H. D. 2001. "Teaching Principles: An Interactive Approach to Language," NJ: Printice Hall.

[2] Arnold, J. 1999. Affect in Language Learning. Cambridge University Press.

[3] Slavin, R. E. 1995. "Cooperative learning: Theory, research and practice," Second Edition. Boston: Allyn \& Bacon.

[4] Min, H. T. 2006. "The Effects of Trained Peer Review on EFL Students' Revision Types and Writing Quality," Journal of Second Language Writing, 15, 118-141.

[5] Ghaith, G.M. 2003. "The Relationship between Cooperative Learning, Perception of Social Support, and Academic Achievement," System, 30(3), 263-273.

[6] Harmer, J. 2003. "How to Teach English," Beijing: Foreign Language Teaching and Research Press. 